\title{
円筒型高温水蒸気電解セルの温度分布予測
}

\begin{tabular}{|c|c|c|c|c|c|}
\hline 正 員 & 永 & 田 & & 進 & (電 総 研) \\
\hline 正 員 & 春 & 日 & 康 & 弘 & (電 総 研) \\
\hline 正 員 & 門 & 馬 & 昭 & 彦 & (電 総 研) \\
\hline 非会員 & 嘉 & 藤 & & 徹 & (電 総 研) \\
\hline
\end{tabular}

\section{Simulation of Temperature Distribution of Tubular Solid Oxide Electrolysis Cell}

Susumu Nagata, Member, Yasuhiro Kasuga, Member, Akihiko Momma, Member, Tohru Kato, Nonmember (Electrotechnical Laboratory)

In this paper, a mathematical simulation of the temperature distribution of a tubular solid oxide electrolysis cell (SOEC) is presented. In the method, the effects of Joule heating, heat-transfer, radiation and heat convection are taken into consideration. As examples, the temperature distributions in the SOEC with an internal high temperature heat-exchanger and with an external high temperature heat-exchanger are calculated. As a result, the temperature distribution with an external high temperature heat-exchanger is smoother, but the current density is kept lower because of the limit of a working temperature. It is also estimated that a lower electrolysis rate contributes to decrease the maximum temperature and to smooth the temperature distribution.

キーワード : 高温水蒸気電解, SOEC, 予測, 内部熱交, 電解率, 電解効率

\section{1. まえがき}

固体電解質を利用した高温水蒸気電解 (Solid Oxide Electrolysis Cell：以下SOEC と略記）による水素の製造 は，高効率が予測されている。そのためSOEC はエネル ギー貯藏およびエネルギー輸送のための水素製造システム として注目を集め始めている(1)。

SOEC は, 水素の酸化反応の際の化学エネルギーの一 部を電気エネルギーとして取り出す固体電解質燃料電池 (SOFC) の逆の反応を行う装置で，水蒸気を電気分解し 水素と酸素を取り出す装置である。SOFCでは発電反応 に伴うエントロピー変化は発熱で, これに電流が流れるた めの内部損失による発熱とが重なり, 電池が加熱されるの でホットスポットができやすい。これを避けるために, 酸 化戍を二重管構造によりリターンフローとして直接発電部 分に導入し, 発電部分の冷却（酸化剂の加熱でもある）を 行う構造が考えられている(2)。他方 SOEC は反応が吸熱 反応であることから, 内部損失による発熱は反応に必要な 熱としてその場で回収されるのでホットスポットはできに くい。従って同じ構造でも SOEC は SOFCに比べて高い 動作電流密度で運転できる。また, 反応に必要な熱の一部 を他の熱機関の排熱で賄えば, 排熱回収が可能で, 電力消
費だけからみた見掛けの電解効率を $100 \%$ 以上にすること ができる。Donitzら ${ }^{(3)}$ は, 他の熱機関の排熱で $150^{\circ} \mathrm{C}$ 程 度に予熱された蒸気を原料とすれば, 電解電圧が $1.3 \mathrm{~V}$ と低くなり, 高い電解効率を得ることができるとしてい る。すなわち，SOECはセル部分に着目すれば，SOFC の逆運転であるが, 高効率な SOEC システムの建設のた めには, SOEC システムが SOFCシステムの単純な逆運 転とはならず，システムが異なったものとなる可能性があ る。

本論文では，コントロールボリューム法(4)を用いて SOEC システム構築のバリエーションを考える基礎とな る温度分布を予測する方法を述べる。また予測例として, 蒸気の加熱を電解容器の外部で行う場合と容器の内部沉設 けた熱交によって行う場合の温度分布の相違などを報告す る。

\section{2. 水蒸気電解システム}

〈2・1〉 システム構成 図 1 に電解セルシステムの峣 略の構成を示す。原料である水は, 低温熱交および予熱器 によって, 温度の低い蒸気へと加熱される。予熱には電 力, 産業廃熱, 太陽熱などが用いられる。

低温の蒸気は, 高温熱交によって動作温度まで加熱され, 


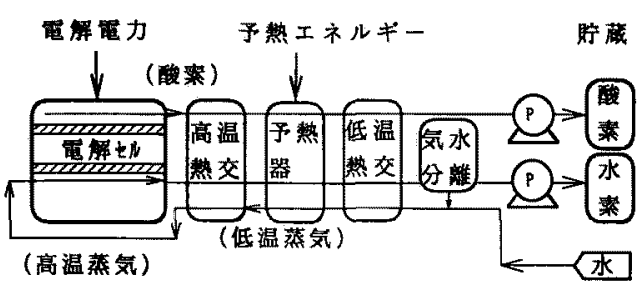

図 1 SOEC システムの模式図

Fig. 1. Schematic of SOEC system.

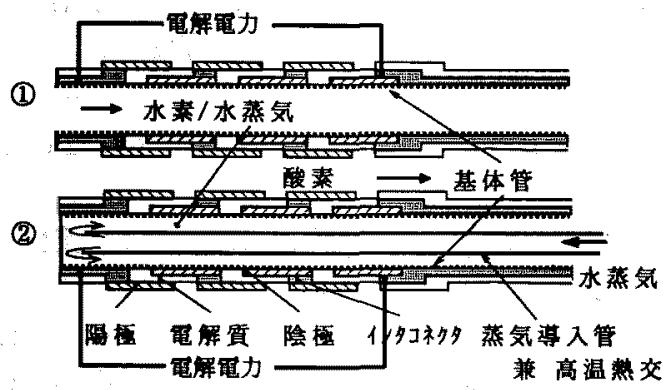

(1) 外部高温熱交形の場合

(2) 内部高温熱艾形の場合

図 2 高温熱交方式による構造の違い

Fig. 2. Difference in structure between two types of high temperature heat-exchanger.

電解セルへ供給される。電解によって製造された水素と酸 素は保有している熱を原料水と熱交換した後，酸素はその まま貯蔵，水素は未電解の水と分離され，貯蔵される。分 離された水は，原料水の一部として再度電解に使用され る。なお電解で製造された水素と酸素の温度が約 $1,000^{\circ} \mathrm{C}$ であるとすると，その保有熱量の合計は，原料水を $100^{\circ} \mathrm{C}$ の蒸気にするために必用なエンタルピーにほほ等しい。従 って，一般的には，約 $1,000^{\circ} \mathrm{C}$ の原料蒸気を得るために は, 図1に示すように予熱器によって排熱以外の熱を供給 する必要がある。

〈2-2〉高温熱交の違いと炎の効果＼cjkstart図 2 に異なった 高温熱交方式をもつ二つの電解セル部分を示す。電解の原 料である蒸気を動作温度まで加熱する方法として, 図 1 に 示したようにセル容器外部に高温熱交を設ける方法（ガス の流机蛙図 2 (1)となる：外部高温熱交方式と呼ぶ)，と図 2(2)に示すように電解セルの内部まで原料蒸気を供給する 管を伸ばしてその管に高温熱交機能をもたせる方法（内部 高温熱交方式と略称）が考えられる。

内部高温熱交方式では，大きめな電解電流によって発生 する内部損失（ジュール損失）の一部をセル内部に設けた 熱交によって，蒸気の加熱に用いることができる。外部高 温熱交の場合は $100^{\circ} \mathrm{C}$ の蒸気と電解温度の蒸気の熱落差 を予熱で補う必要があるから，同じ電解電流（ほ浔同じ内 部熱損失が発生する) で比較すると，内部高温熱交の場合 より容器に対する熱入力が増えるので動作温度が高くな る。換言すれば，セルの動作温度を耐久性からある温度範 囲に限定する必要がある場合は，内部高温熱交方式とした ほうが高い電流密度で電解を行える利点がある。従って内
部高温熱交方式と予熱を併用すれば，比較的低い動作温度 と高い電流密度で SOEC システムの運転が可能となるも のと予測される。次の第 3 章に扔いて，これらの定性的な 予測を，定量的に議論するための予測モデルを構筑し，第 4 章において現実的なパラメータを用いた場合の温度分布 を議論する。

\section{3. モデルの構築}

〈3・1〉 電解セルおよび容器 電解セルとして, 円筒 型の SOEC を採用する。円筒型セルの場合, 図 2 (2)に示 すように，セラミックなどによる蒸気導入管をセル内部に 挿入し，熱交を構成することができる。この熱交によって 低温蒸気を高温の動作温度まで加熱することができる。電 解セルは図 2 に示すように, 基体管の上に構成した円筒横 縞型(5)を用いるものとする。単スタックは $0.012 \mathrm{~m}$ の単 位セル 30 個を $0.006 \mathrm{~m}$ のインタコネクタで直列に接続 し, 全長 $0.54 \mathrm{~m}$ とする。温度分布は, 完全に熱絶緑した 容器に 1 本のスタックが置かれているものとして求める。

〈3・2〉 ガス成分の計算 簡単のため流れに沿ったガ ス濃度の変化を, ピストン流で近似する。また電極内の流 れも径方向の一次元流で近似する。流れに沿ったガス成分 のモル流量の変化は，酸素や水素と水蒸気の混合ガス（以 下，電解ガスと呼ぶ）に対して間隔 $H=0.002 \mathrm{~m}$ のコント ロールボリューム（以下 $\mathrm{CV}$ と略記）に分割し， CV 間の ガス成分バランスから求める。なお隣り合った $\mathrm{CV}$ は, 電 解ガスの流れ方向にjによって付加番号し, $\mathrm{CV}(j-1)$, $\mathrm{CV}(j), \mathrm{CV}(j+1)$ などと表示するものとする。いま図 3 に示す電解セルの区間 $H$ の電解電流を $I_{e}(j)$ とすると, $\mathrm{CV}(j-1)$ と $\mathrm{CV}(j)$ の水素, 水蒸気, 酸素のモル流量 $(\mathrm{mol} / \mathrm{s})$ の関係は，次のように与えることができる。

$$
\begin{aligned}
& G_{\mathrm{H}_{2}}(j)=G_{\mathrm{H}_{2}}(j-1)+I_{e}(j) / 2 F_{a} \\
& G_{\mathrm{H}_{2} \mathrm{O}}(j)=G_{\mathrm{H}_{2} \mathrm{O}} \mathrm{O}(j-1)-I_{e}(j) / 2 F_{a} \\
& G_{\mathrm{O}_{2}}(j)=G_{\mathrm{O}_{2}}(j-1)+I_{e}(j) / 4 F_{a} \\
& \text { ここに, } G_{\mathrm{H}_{2}} \text { : 水素のモル流量, } G_{\mathrm{H}_{2} \mathrm{O}} \text { : 水蒸気の } \\
& \text { モル流量, } G_{0_{2}} \text { : 酸素のモル流量, } F_{a} \text { : ファラデ } \\
& \text { 一常数 }
\end{aligned}
$$

〈3・3〉 電流分布と電解電力の計算 内部抵抗は図 3 に示すように，はしご型回路で近似して計算する。

いま図 $3 の I_{e}(j), I_{e}(j+1)$ を含む閉回路に着目すると 枝路電流の関係は次式で与えられる(6)。

$$
\begin{aligned}
& I_{e}(j+1)=\left[V_{p}(j)-\dot{V}_{p}(j+1)+I_{e}(j) R_{e}(j)+I_{c}(j)\right. \\
& \left.\times\left(R_{c}+R_{a}\right)-I_{L} R_{a}-E(j+1)+E(j)\right] / \\
& R_{e}(j+1)
\end{aligned}
$$




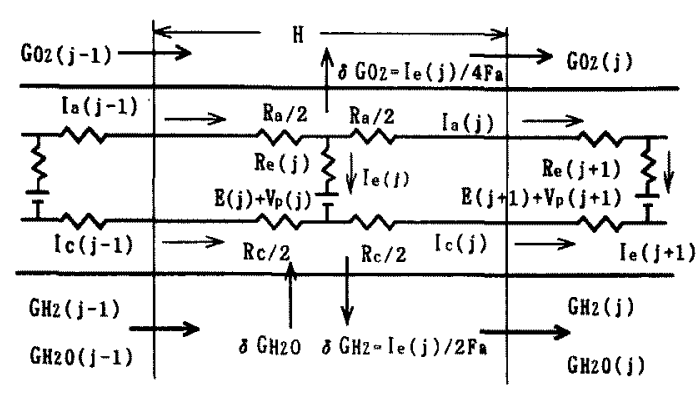

図 $3 \mathrm{SOEC}$ セルの電気的等価回路

Fig. 3. Equivalent circuit of SOEC.

表 1 抵抗パラメータ

Table 1. Resistance parameter.

基体管：直径 $D_{s}=0.014 \mathrm{~m}$ 厚み $t_{s}=0.002 \mathrm{~m}$

練孔徍 $d=3 \cdot 10^{-6} \mathrm{~m}$ 基体管中心間篇 $=D_{a}+t_{a}+0.002 \mathrm{~m}$

\begin{tabular}{|c|c|c|c|}
\hline \multicolumn{4}{|c|}{ 電解セル部品の $1,273 \mathrm{~K}$ における抵抗 } \\
\hline 楎成材料 & $\begin{array}{l}\text { 導電率 } \\
(\mathrm{S} / \mathrm{m}) \\
\end{array}$ & $\begin{array}{c}\begin{array}{c}\text { 膜厚 } \\
\left(10^{-8} \mathrm{~m}\right)\end{array} \\
\end{array}$ & $\begin{array}{c}\text { 抵抗パラメータ } \\
(1 / \mathrm{S}) \\
\end{array}$ \\
\hline 陽極 & $S_{a}=0.78$ & $t_{a}=1,000$ & $r_{a}=1 / S_{a} t_{a}$ \\
\hline 陰極 & $S_{c}=10$ & $t_{c}=150$ & $r_{c}=1 / S_{c} t_{c}$ \\
\hline 電解質 & $S_{e}=0.001$ & $t_{e}=50$ & $r_{e}=t_{e} / S_{e}$ \\
\hline インタコネクタ & $S_{i}=0.02$ & $t_{i}=50$ & $r_{i}=t_{i} / S_{i}$ \\
\hline
\end{tabular}

め。

$R_{a}=r_{a} H / \pi D_{a}, \quad R_{c}=r_{c} H / \pi D_{c}, \quad R_{e}=r_{e} / H \pi D_{e}$

ここに, $D_{a}$ : 陽極の平均直径, $D_{c}$ : 陰極の平均

直径, $D_{e}$ : 電解質の平均直径

(4)式を各回路に展開し， $I_{L} ， E$ および $V_{p}$ を既知とす れば枝路電流 $I_{e}, I_{c} ， I_{a}$ を求めることができる。なお表 1 の中で $S_{e}$ のみが温度 $T(\mathrm{~K})$ に対して次式のように依存性 があるものとする(8)。

$$
S_{e}(T)=2.8 \cdot \exp (-10,100 / T)
$$

活性化分極 $V_{a}$ は電流密度 $J_{e}\left(=I_{e} / \pi D_{e} H\right)$ に対し次式の Tafel の式(9) で近似する。

$$
V_{a}=0.074 \cdot(T / 1273) \cdot \ln \left(J_{e} / J_{0}\right)
$$

たた゚し，係数およひ，交換電流密度 $J_{0}$ は実測から求めた。

$$
J_{0}=10^{(-7520 / \mathrm{T}+8.51)}
$$

多孔質電極（あるいは基体管）中では, 電解電流に対応 した水素・水蒸気の対向流が発生し, 拡散係数が主流の 1 割程度（付録参照）であるから，大きなガス濃度分布が発 生する。この濃度分布の起電力に及海す効果が電解におけ るガス濃度分極 $V_{c}$ である。電極内のガスの流れを径方向 （rで表す）の一次元流で近似し，濃度分布を並列紐孔モ デル(10)を用いて求める。水素と水蒸気が多孔質材料中を 対向して流れるときの圧力および濃度の分布は以下のよう に近似できる。

成分 1 (水素) の単位面積当たりのモル流量を $J_{1}$, 成分 2 (水蒸気) のそれを $J_{2}$ とすると, 電極の厚み方向（径方 向）の全圧 $P$ の変化は次式で与えられる。 $d P / d r=-\left(J_{t}-\beta J_{1}\right) R T / D_{22}$ ここに, $J_{t}=J_{1}+J_{2}, \beta=1-D_{2} / D_{1}, D_{i}=\psi(d / 3)$ $\times\left(8 R T / \pi M_{i}\right)^{0.5}, \phi=$ 拡散低減率, $d$ : 多孔質の 細孔径, $M_{i}$ : ガス $i$ の $1 \mathrm{~mol}$ 当たりの質量, $D_{22}$ $=D_{2}\left(1+\left(X_{1} / D_{1}+X_{2} / D_{2}\right) B P / \mu\right), X_{i}$ : 成分 $i \sigma$ モル分率, $R$ : 気体常数, $B=\psi=d^{2} / 32, \mu$ : ガス 1,20 混合粘性率, $X_{2}=1-X_{1}$ また成分 1 のモル分率 $X_{1}$ の変化は次式で与えられる。 $\left(d X_{1} / d r\right) \alpha P D / R T=-J_{1}+X_{1} \alpha J_{t}+\left(J_{t}-\beta J_{1}\right)\left[\alpha D X_{1}\right.$ $\left.+X_{1}(1-\alpha) B P / \mu\right] / D_{22}$

ここに, $\alpha=D_{1} /\left(D_{1}+D\right), D=$ 成分 1,2 の電

極内におけるガス拡散係数

水素, 水蒸気, 酸素の単位面積当たりのモル流量の関係 は次式で与えることができる。

$$
J_{\mathrm{H}_{2}}=-J_{\mathrm{H}_{2} \mathrm{O}}=-2 J_{\mathrm{O}_{2}}=-J_{e} / 2 F_{a}
$$

(11)式を(9)，(10)式に代入し，微分方程式を解き $P(r), X_{i}(r)$ を求めることができたとすると,ガス成分 の分圧 $P_{i}(r)$ は次式で与えられる。

$$
P_{i}(r)=P(\dot{r}) X_{i}(r)
$$

酸素を成分 1 とする場合は, $J_{2}=0, D_{1}=D_{2}, X_{2}=0$ と し，（9）式のみ考虑する。

起電力 $E$ は, 電解ガスの水蒸気の分圧 $P_{\mathrm{H}_{2} \mathrm{O}}$, 水素の分 圧 $P_{\mathrm{H}_{2}}$, 生成酸素ガス压 $P_{\mathrm{O}_{2}}$ に対して次式で与えられる。

$$
\begin{aligned}
& E=\frac{\Delta G_{\tau}{ }^{o}+R T \ln \left(P_{\mathrm{H}_{2}} \cdot\left(P_{\mathrm{O}_{2}}\right)^{0.5} / P_{\mathrm{H}_{2} \mathrm{O}}\right]}{2 F_{a}} \\
& \text { ここに, } G_{r}{ }^{\circ}=-\Delta G_{\mathrm{H}_{2} \mathrm{O}}^{o}(T), \Delta G_{\mathrm{H}_{2} \mathrm{O}}^{o}(T) \text { : 水蒸気 } \\
& T \text { における標準生成自由エネルギー }
\end{aligned}
$$

濃度分極 $V_{c}$ は, 電極と電解質界面のガス分圧による起 電力と主流のガス分圧による起電力との差である。

$\mathrm{CV}(j)$ 内に供給される電力は, 電流分布の計算から求 めたジュール損, 活性化損, 濃度分極損および電解電力の 合計 $Q_{\text {gene }}$ で与えることができる。

$$
\begin{aligned}
Q_{\text {gene }}= & I_{e}(j)\left[E(j)+V_{p}(j)+I_{e}(j) R_{e}(j)\right]+R_{c}\left(I_{c}(j)^{2}\right. \\
& \left.+I_{c}(j-1)^{2}\right] / 2+R_{a}\left[I_{a}(j)^{2}+I_{a}(j-1)^{2}\right] / 2
\end{aligned}
$$

〈3.4〉熱移動の計算等価電気回路に合わせて分 割した CV に対し，図 4 に示すように，左右上下の CV 間 の熱移動を求める。ガスのCV 間の熱移動は, 対流と熱质 導の両方を考虑した。流速の遅い酸素では，酸素ガスの浼 度 $C_{\mathrm{O}_{2}}\left(\mathrm{~mol} / \mathrm{m}^{3}\right)$, 速度 $V(\mathrm{~m} / \mathrm{s})$, 熱伝導率 $k_{\mathrm{O}_{2}}(\mathrm{~W} / \mathrm{m} / \mathrm{K})$, 熱容量 $\mathrm{O}_{\mathrm{pO}}(\mathrm{J} / \mathrm{K} / \mathrm{mol})$ とすると，酸素の熱移動に対する ペクレ数 $=\mathrm{C}_{\mathrm{PO}_{2}} \cdot \mathrm{C}_{\mathrm{O}_{2}} \cdot V \cdot H / k_{\mathrm{O}_{2}}$ は約 2 以下であるので，対 流による熱移動と熱伝導による熱移動の両方を考慮する。 水素水蒸気の混合ガスではペクレ数が約 8 と大きいので, 対流による熱移動のみを考慮し熱伝導の効果は無視する。 温度 $T_{0}(\mathrm{~K})$ を基準にした温度 $T(\mathrm{~K})$ のガス $i$ のンタ ルピー $H_{i}(T)$ は次式によって与えられる(11)。

$$
H_{i}(T)=\Delta H_{i}\left(T_{0}\right)+L_{v, i}{ }^{0}+\int_{T_{0}}^{T} C_{p, i}(T) d T
$$




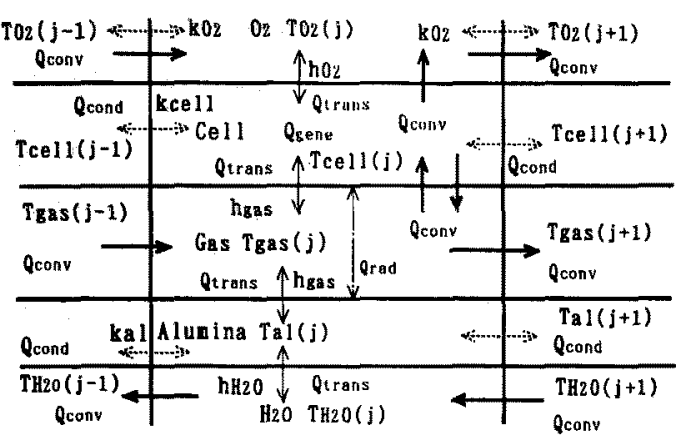

図 $4 \mathrm{CV}$ 間の熱移動の相関

Fig. 4. Relation of heat migration among CVs.

ここに, $\Delta H_{i}\left(T_{0}\right): T_{0}$ におけるガス $i$ の生成工 ンタルピー, $L_{v, i}{ }^{0}$ : 基準温度 $T_{0} に$ におる蒸発熱 ガスの流れによって，ガスの風上の $\operatorname{CV}(j-1)$ から風下 の CV $(j)$ へ移動する熱移動 $Q_{\text {conv }}$ は，風上法 ${ }^{(4)}$ を用いて，

$Q_{\mathrm{conv}}=\Sigma G_{i}(j-1) \cdot H_{i}\left(T_{j-1}\right)+Q_{k}$

ここに, $G_{i}(j-1)$ : ガス成分 $i の \operatorname{CV}(j-1)$ にお

けるモル流量， $Q_{k}$ ：ガスの熱伝導による熱移動 ただし

$Q_{k}=k_{\text {gas }} \cdot A_{\text {gas }} \cdot[T(j-1)-T(j)] / H$

ここに，A $A_{\mathrm{gas}}$ ：ガス CV の流れに直行する部分の

断面積, $k_{\mathrm{gas}}$ : ガスの熱伝導率

固体とガス間の熱伝達による熱移動, 例えば電解セルか ら電解ガスへの熱移動 $Q_{\text {trans }}$ は次式によって与える。

$Q_{\text {trans }}=A_{\text {cent }} \cdot h_{\text {gas }}\left(T_{\text {cell }}-T_{\text {gas }}\right)$

ここに， $A_{\text {cell }}: \mathrm{CV}$ のガス側面積, $h_{\text {gas }}$ : セルと

ガス間の熱伝達係数

電解セル（電極，電解質および基体管は熱的に一体化し たブロックとして近似)や蒸気導入管のCV $(j-1)$ から $\mathrm{CV}(j)$ への熱伝導による熱移動 $Q_{\text {cond }}$ は

$Q_{\text {cond }}=A_{\text {solld }}\left[T_{\text {solld }}(j-1)-T_{\text {sond }}(j)\right] k_{s} / H$

ここに， $A_{\text {solld }}$ ：隣接した固体 CV 間の断面積,

$T_{\text {solld }}(j), T_{\text {solld }}(j-1):$ 隣接した固体 $\mathrm{CV}$ の温度

$(\mathrm{K}), k_{s}$ : 固体の熱伝導率

ガスを挟んで向かい合った固体間の熱移動には, 輻射も 考慮する（カ゚ス自体の輻射は無視する）。例えば, 蒸気導

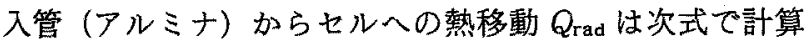
する。

$Q_{\mathrm{rad}}=\frac{5.67 \cdot 10^{-8}\left(T_{\mathrm{al}}{ }^{4}-T_{\text {cell }}{ }^{4}\right) \varepsilon}{1 / A_{\mathrm{al}}+(1-\varepsilon) / A_{\text {cell }}}$

ここに, $\varepsilon:$ 放射率 $=0.6, A_{\mathrm{a} 1}:$ アルミナ管のガ

ス側 CV 断面積, $T_{\mathrm{a} 1}:$ アルミナ管の温度 $(\mathrm{K})$,

$T_{\text {cenl }}$ : セルの温度 $(\mathrm{K})$

〈3.5〉CV の熱バランスと温度分布の計算 図 4 に 示すように，ガスおよび固体の各 CVの温度は，その左右 上下に隣接する（輻射の場合はガスの向こうの固体との熱 も考慮する) CVとの熱バランスから求めることができ る。ある着目した CV に流入する熱の総和は定常状態では 零である。
表 2 熱物性值

Table 2. Thermophysical properties.

\begin{tabular}{|c|c|c|}
\hline 桡成材料 & $\begin{array}{l}\text { 熱伝遵率 } \\
(\mathrm{W} / \mathrm{m} \cdot \mathrm{K})\end{array}$ & $\begin{array}{l}\text { 拉散係数 } \\
\left(10^{-4} \mathrm{~m}^{2} / \mathrm{s}\right)\end{array}$ \\
\hline 晹極 & 6.0 at $\sim 1,273 \mathrm{~K}$ & 自由空間の $10 \%$ \\
\hline 陰極 & 11 at $\sim 1,273 \mathrm{~K}$ & 自由空間の $10 \%$ \\
\hline 電解質 & 2.7 at $\sim 1,273 \mathrm{~K}$ & \\
\hline アルミナ & 2.6 at $\sim 1,273 \mathrm{~K}$ & (低純度品) \\
\hline インタコネクタ & 6.0 at $\sim 1,273 \mathrm{~K}$ & \\
\hline 基体管 & 1.1 at $\sim 1,273 \mathrm{~K}$ & 自由空間の $10 \%$ \\
\hline 水素 & $0.305(\mathrm{~T} / 600)^{0.78}$ & \multirow{2}{*}{$8.83(T / 1,272)^{1.84}$} \\
\hline 水蒸気 & $0.097(T / 1,000)^{1.44}$ & \\
\hline 酸菜 & $0.073(T / 1,000)^{0.78}$ & $2.36(T / 1,273)^{1.66}$ \\
\hline
\end{tabular}

$$
0=\Sigma\left(Q_{\text {rad }}+Q_{\text {trans }}+Q_{\text {cond }}+Q_{\text {gene }}+Q_{\text {conv }}\right)
$$

ただし，CV の特性によって(21) 式の中で用いる熱移動 の項目と正負の符号は適宜選択するものとする。

ガスあるいは固体において，熱伝䙡および熱伝達は (18)，(19)式に見るように，温度の一次関数である。また 流れによる熱移動は(15)式の右辺第 3 項の積分を, 熱力学 データ ${ }^{(12)} に よ り$ 温度の近似関数として与え, 更に次式に よって温度の関数として与えれば,

$$
\left\langle C_{p_{i}}(T)\right\rangle=\frac{1}{\left(T-T_{0}\right)} \int_{T_{0}}^{T} C_{p_{i}}(T) d T
$$

流れによる熱移動も温度の一次関数となる。ただし， $\left\langle C_{p i}(T)\right\rangle$ 中の温度 $T$ は, 初期值としてあらかじめ与 光る必要がある。(21)式において着目したCVの温度 $T$ の一次項を含む項とそれ以外の項に分ければ，隣接した CVの温度およびTの高次項に対して逐次的に着目した CV の温度 $T$ を求めることができる。

この方法で着目すべき CV を順次移動させながら全体の 温度分布を計算し，計算が一巡したところで, 各 $\mathrm{CV}$ の温 度によって〈 $\left.C_{p i}(T)\right\rangle$ などの熱定数を修正し, 再度 $\mathrm{CV} の$ 温度を計算し直す。この操作を繰り返し, 各 CV の温度変 化が微小となった時点で, 全体の温度分布を得たものとす る。

〈3.6〉熱物性值計算に用いた熱物性値のうち，固 体の熱伝導率 ${ }^{(13)}$ は温度変化に対する実測デ一タがないの で温度変化にかかわらず一定とした。気体の熱伝導率は熱 物性表(14) の值をべき乗で近似した。抎散係数は ChapmanEnskogの式(15)により温度依存性を求め,これをぺき乗 で近似した。これらの熱物性值を表 2 に示す。（9）式で用 いる混合気体の粘性率は次式(16)によって求めた。

$$
\begin{gathered}
\mu=\Sigma \frac{X_{i} \mu_{i}}{\sum X_{i} \phi_{i j}} \ldots \ldots \ldots \ldots \ldots \ldots \ldots \ldots \ldots \ldots \ldots \ldots \ldots \ldots \ldots \\
\phi_{i j}=\frac{\left[1+\left(\frac{\mu_{i}}{\mu_{j}}\right)^{0.5}\left(\frac{M_{i}}{M_{j}}\right)^{0.25}\right]^{2}}{2^{1.5}\left(1+M_{i} / M_{j}\right)^{0.5}}\left(\phi_{i i}=1\right)
\end{gathered}
$$

平均熱伝達係数は, 流路の相当直径 $d_{e}$, 流体の熱伝導 率 $k$ ，ヌッセルト数 $\mathrm{Nu}$ が既知であれば，次式によって与 えられる。 
$h=\mathrm{Nu} k / d_{e}$

ここに, $d_{e}=4 S / \Sigma l, \Sigma l:$ 濡れぶち全長, $S:$ 流

路面積

生成ガス $\left(\mathrm{H}_{2}\right.$ と $\mathrm{H}_{2} \mathrm{O}$ の混合ガスあるいは $\mathrm{O}_{2}$ ガス) の流 れは，壁温一定の発達した層流として近似し， $\mathrm{Nu}=$ $3.66^{(17)}$ を用いる。ただし，電解ガスの熱伝導率は，次 式(18)で求める。

$$
\begin{aligned}
& k=\sum \frac{X_{i} k_{i}}{\sum X_{i} \phi_{i j}} \quad\left(\phi_{i i}=1\right) \\
& \text { ここに， } k_{i} \text { : ガス } i \text { の熱伝導率， } \phi_{i j} \text { は } \\
& \phi_{i j}=0.25\left\{1+\left[\frac{\mu_{i}}{\mu_{j}}\left(M_{i} / M_{j}\right)^{3 / 4} \frac{1+\left(S_{i} / T\right)}{1+\left(S_{i} / T\right)}\right]^{0.5}\right\}^{2} \\
& \times\left[\frac{1+\left(S_{i j} / T\right)}{1+\left(S_{i} / T\right)}\right]
\end{aligned}
$$

ここで, $S_{i}=$ ガス $i$ サザランド数, $S_{i j}$

$=.733\left(S_{i} S_{j}\right)^{0.5}$

原料の水蒸気は，温度変化が大きいので熱流束一定の発 達した層流として近似し， $\mathrm{Nu}=4.36^{(16)}$ とする。

\section{4. 温度分布計算例}

基本的には図 2 の構造を用いるものとし，入り口部分 $0.02 \mathrm{~m}$ (位置 $0 \sim 0.02 \mathrm{~m}$ ), 電解セル部分 $0.54 \mathrm{~m}$ (位置 $0.02 \sim 0.56 \mathrm{~m})$ ，七ル下流部分 $0.1 \mathrm{~m}(0.56 \sim 0.66 \mathrm{~m})$ の 温度分布を計算した。低温熱交へ供給する原料水の温度を $25^{\circ} \mathrm{C}$ ，低温熱交からのガス（一部水を含む）出口温度を $25^{\circ} \mathrm{C}$ と仮定（容器からの熱損失を無視した）した。高温 熱交への蒸気入り口温度は, 高温熱交の出口温度, 予熱器 入力, 低温熱交からのガス出口温度, 原料水供給温度, 各 部の流量などのエネルギーバランスから求めた。また入り 口水素濃度を $3 \%$, 水蒸気の電解率 $U_{f}$ を $80 \%$ とした。

図1のように，図 2 の(1)に示すように内部に高温熱交構 造がなく，1,273 K まで予熱した蒸気を上流（四 2 (1) の左 端）からセルに供給した場合の，笔解セルおよび下流の温 度分布の予测を図 5 に示す。

セルとガスの温度がほとんど差がないので, 図 5 ではセ ルの温度のみ示す（七ルの左端の境界条件は熱絶縁とした ので，入り口水蒸気温度 $1,273 \mathrm{~K}$ とは若干違っている)。 電解電流密度が $2 \mathrm{kA} / \mathrm{m}^{2}$ と低い場合は，入り口付近では 水蒸気濃度が高く電解反応の吸熱が内部損失による発熱に 勝るので, 温度が下がっている。出口付近では, 水蒸気濃 度が減り吸熱が減少するので温度は回復してくるが，出口 温度は，入り口温度より約 $90^{\circ} \mathrm{C}$ 下がっている。電解反応 の吸熱は電流に比例する（温度の行布を考えない場合）の みであるが，内部損失の内の電流の 2 乗に比例する部分が 大きいので, 電流密度を增やすと電解反応の熱に比べ内部 損失が相対的に増え出口温度が上昇する。電流密度 $4 \mathrm{kA} /$

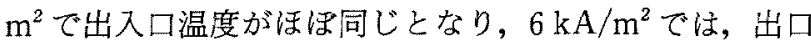
温度が入り口温度より約 $90^{\circ} \mathrm{C}$ 増加している。すなわちセ ルの耐熱温度を考慮すれば，電流密度をある值以下に押さ える必要があると予測される。この例では，耐熱温度の上

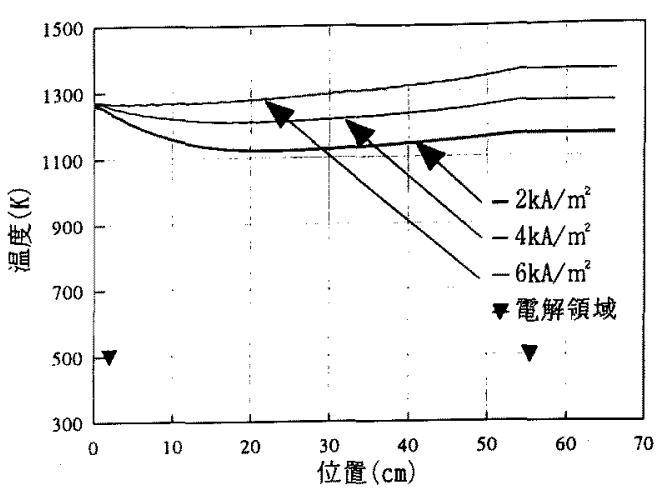

電流密度 $J_{e}=2 \sim 6 \mathrm{kA} / \mathrm{m}^{2}$

図 5 外部高温熱交の場合の温度分布 Fig. 5. Calcurated temperature distribution using pre-heated vapor $(1,273 \mathrm{~K})$ with external high temperature heat-exchanger.

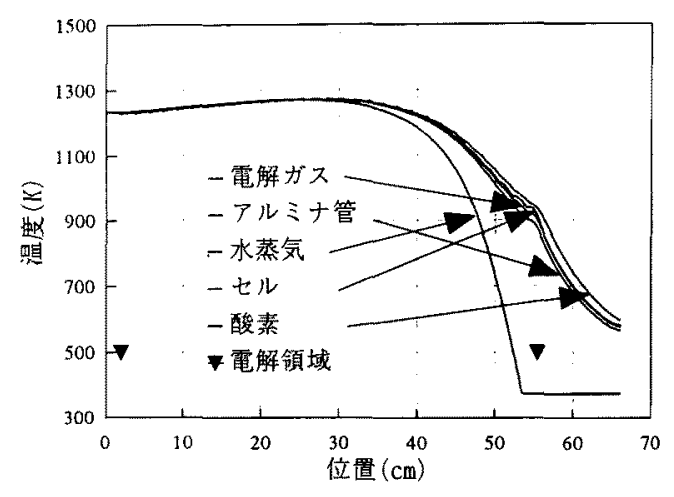

予熱なし, 電流密度 $J_{e}=6 \mathrm{kA} / \mathrm{m}^{2}$

図 6 内部高温熱交のある場合の温度分布

Fig. 6. Temperature distribution with internal high temperature heat-exchanger.

限を $1,273 \mathrm{~K}$ 近傍とすれば，電流密度の限界は $4 \mathrm{kA} / \mathrm{m}^{2}$ となる。

図 6 は，図 2 の(2)に示すような内部高温熱交方式で，下 流（図 2 (2)の右端）から蒸気を供給する場合の温度分布を 予測したものである。この場合，原料は低温熱交から予熱 器を経て電解セル中の高温熱交に入り, リターンフローと してセルへ供給される。容器内部で蒸気を加熱するため に, 電流密度を $6 \mathrm{kA} / \mathrm{m}^{2}$ とし, 内部損失を増やしている。 しかし，高温熱交に供給される出口ガスの熱量は十分では なく, 出口付近の温度は急激に下がっている。また高温熱 交への入り口付近では（図6の右端），原料水は完全に水 蒸気になりきっていない状況である。この例は蒸気導入管 に熱衝撃を与えるので，現実的でない。

図 7 は，図6の場合に拈いて電解率 $U_{f} を 80 \%$ か 40\%へ変えた場合の水蒸気とセルの温度を示す（繁雑を避 けるため水蒸気とセルの温度のみ示す)。電解率を下げる ことによって全体の温度が少し下がるが, 出口電解がスの 中の水蒸気の濃度が増えるため, 入り口蒸気と熱交換して もそれほど出ロガス温度は下がらず，また供給蒸気も入り 


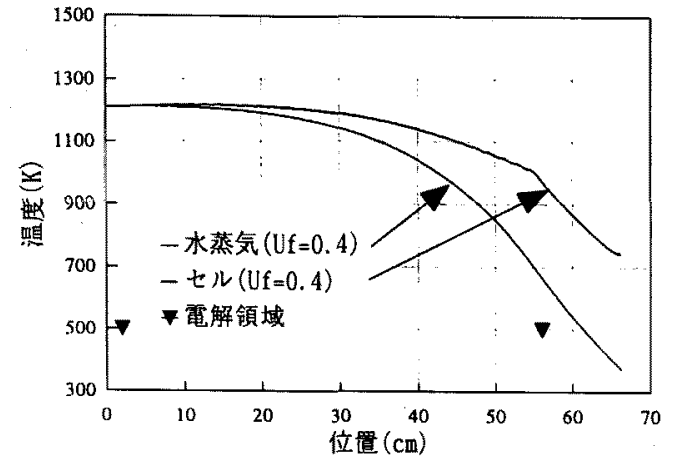

電流密度 $J_{e}=6 \mathrm{kA} / \mathrm{m}^{2}$, 予熱なし

図 7 電解率を $40 \%$ にした場合の温度分布

Fig. 7. Temperature distribution at $U_{f}=40 \%$.

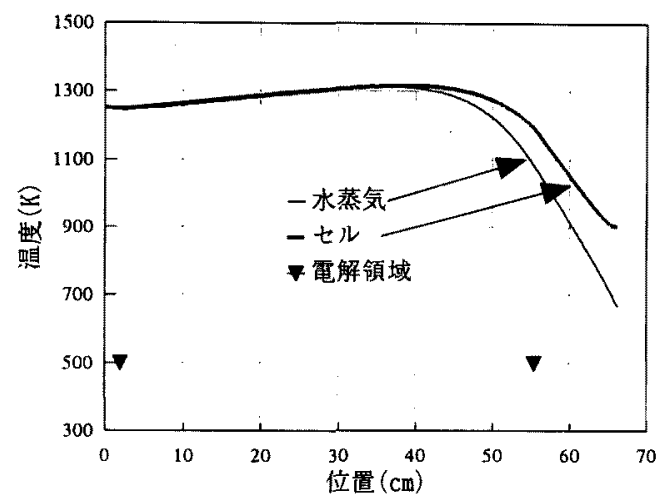

$50 \%$ 予熱, $J_{e}=6 \mathrm{kA} / \mathrm{m}^{2}$

図 8 予熱と内部高温熱交のある場合の温度分布

Fig. 8. Temperature distribution with pre-heating and internal heat-exchanger.

ロで水を含まない乾き蒸気になる。従って，電解率を 40\%以下にすれば高温熱交へは蒸気のみが入ってくること が予想される。

図 8 は，原料水を蒸気にするに要する熱量の $50 \%$ の電 力で予熱し，ほかは図 6 と同じとした場合の温度分布の予 測である（繁雑を避けるため水蒸気とセルの温度のみ示 す)。この場合は高温熱交入り口の原料水蒸気の温度は約 $700 \mathrm{~K}$ まで高められ, セル温度の最高值も図 6 の場合に比 較し約 $60 \mathrm{~K}$ 高くなっている。

\section{5. まとめ}

熱の移動, 内部熱損失, 輻射, 電流分布などを考慮した 高温水蒸気電解セルの温度分布予測モデルを製作し, 熱交 換方式，電解率切よび原料水の予熱などによるセルの温度 分布の特徴を数量的に検討した。その結果を要約すると次 のとおりである。

（1）電解容器の外部に設けた高温熱交で原料蒸気を動 作温度まで加熱する場合，容器内部に高温熱交を設ける場 合に比べて温度分布が平滑であるが, 電解セルの耐久温度 を考慮した場合，電解電流が低く押さえられる。

（2）予熱を行わないで, 容器内部に設けた高温熱交の みで原料蒸気を動作温度まで加熱する場合は，電解率を
80\%程度に高くすれば，原料水が完全に蒸気になりきらな いで高温熱交に入る可能性がある。

（3）前記 (2) 項の場合でも電解率を $40 \%$ 程度に下げ れば，高温熱交への入り口で原料水を蒸気とすることがで きる。

（4）予熱器で原料水の蒸発熱の 50\%程度の熱を供給 すれば，セルの平均動作温度はわずかに上昇するが, この 場合も (2)項で述べた現象は避けることができる。

(平成 7 年 11 月 1 日受付, 同 8 年 2 月 26 日再受付)

$$
\text { 文献 }
$$

（1）楠 敬・菊岡泰平・馬腰俊光・上田三男・宮本 均・中森信夫： 「電力唄蔵用 SOE/SOFC リパーシブルセルの開発」, 動力・エネ ルギー技術シンポジウム (神戸)、A 17 (平6)

(2) K. Shinozaki, S. Washio. T. Satomi \& S. Koike: "VERIFICA TION TEST OF $25 \mathrm{~kW}$ CLASS SOFC COGENERATION SYSTEM", 3rd Inter. Sympo. on SOFCs, 684-689 (1993)

(3) W. Donitz, G. Dietrich, E. Erdle \& R. Streicher : "ELECTRO CHEMICAL HIGH TEMPERATURE TECHNOLOGY FOR HYDROGEN PRODUCTION OR DIRECT ELECTRICITY GENERATION", Int. J. Hydrogen Energy, 13, No. 5 283-287 (1988)

（4） スハス V.パタンカー(水谷・香月訳）：コンピュー夕による熱と 流れの数值解析 (昭 60) 森北出版

(5) S. Kaneko, T. Gengo, S. Uchida \& Y. Yamauchi : "RESEARCH AND DEVELOPMENT OF SOLID OXIDE FUEL CELL", 2ND Int. Sympo. on SOFCs, 35-42 (1991)

（6）永田進・春日康弘：「二次元ガス㹡散を考慮した円简型固体電解 質燃料電池の出力特性の予湘」, 電学諭 B, 112, 271-274 (平 4-3)

(7) R. J. Bratton, P. Reicher \& L. W. Montgomery: "FUEL CELL PRODUCTION PROGRESS CONTROL AND QUALI FICATION OF FINISHED CELLS", Fuel Cell Seminar Abs, p. 80 (1986)

（8）大野吉弘・加賀保男・永田 進：「固体暼解質燃料麗池の製作と動 作特性江関する研究」, 電学論 B 106, 694 (昭 61-8)

（9）井上・相沢・藤鳦：電気化学測定法, p. 143 (昭 60) 技報堂出版

(10) 丸本健二・綾 淳・松井安次:「力゙ス透過率計測による固体電解 質燃料電池構成要素の誈価」，機会学論, 56, No. 532, 268 273 (平2)

(11) 浅野：バソコンで解く化学工学 p. 156 (平 3) 丸盖

(12) D. R. Stull, et al.: JANAF Thermochemical Tables (1965)

(13) K. Kanamura \& 2. Takehara: "Temperature and Thermal Stress Distribution in a Tubular Solid Oxide Fuel Cell", Bull. Chemi. Soc. Jpn., 66, No. 102800 (1993)

（14） 日本機械学会編：伝熱工学瓷料 (改言 4 版) p. 329（昭 61）

(15) R. B. Bird, W. e. Stewart \& Ed. N. Lihtfoot: TRANSPORT PHENOMENA, Wiley Int. ED p. 511 (1960)

(16) L. A. Bromlly \& C. R. Wilke: Ind. Eng. Chem., 43, 1641 (1951)

（17）日本機械学会編：伝熱工学資料（改范 4 版）p. 51 (昭 61)

(18) L. A. Bromlly \& C. R. Wilke: Ind. Eng. Chem., 42, 1508 (1950)

（19）化学工学会編：化学工学便覽 p. 154: 1111 (昭 63) 丸羓

(20) 加賀・大野・中島：「固体電解質形燃料電池潔成要素のガス透過性 評価に関する研究」, 電学論 B, 109146 (平元-4)

\section{付 録}

電極内の有効ガス拡散係数すは，自由空間におけるガス 拡散係数をD free，電極（あるいは基板）の空隙率を $\varepsilon_{a}$, 細孔の屈曲係数を $q$ とすると次式で与えられる

$$
D=D_{\text {tree }} \times \varepsilon_{a} / q
$$

基体管扔よび電極では $\varepsilon_{a}=0.3 \sim 0.4$ である(20)。

また $q$ は 3〜6とされる(19)。従ってD/D free は $0.05 \sim 0.13$ 程度となる。そのため本論文では D/D free 0.1 とした。 


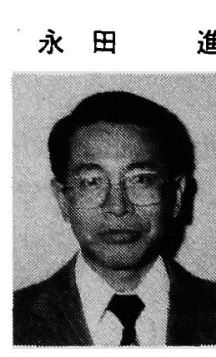

准（正員）1941年 7 月 15 日生。1966 年 3 月広島 大学大学院工学研究科修士課程 (電気工学専攻) 修了。同年 4 月電気試験所（現，電子技術総合 研究所）入所。MHD発電の研究開発を経て, 現在, 固体電解質燃料電池の研究開発に従事。 1982 年電気学会進歩賞受賞。

春 日 康 弘（正員） 1944 年 4 月 5 日生。1967 年 3 月東京電 機大学 II部電子工学科卒業。1 1963 年 4 月電気試 験所（現, 電子技術総合研究所入所）。原子力発 電の安全性, 熱電子発電の研究開発を経て, 現 在, 固体電解質燃料電池および脱硝の研究開発 に従事。

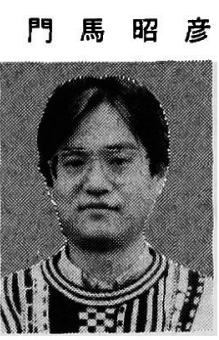

(正員) 1956 年 1 月 9 日生。1985 年東京工業大 学大学院博士課程（金属工学専攻）修了。1989 年 4 月電子技術総合研究所入所。固体電解質燃 料電池の研究開発に従事。

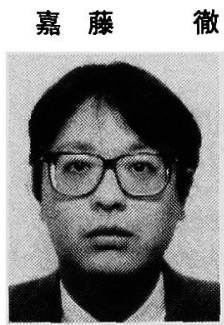

（非会員）1963 年 2 月 20 生。1991 年東北大学 大学院博士課程（電子工学専攻）修了。1992年 電子技術総合研究所入所。固体電解質燃料電池 の研究開発に従事。 